\title{
Penciptaan Naskah Drama Ambu Hawuk Berdasarkan Tradisi Lisan dan Perspektif Jender
}

\author{
Budi Darma ${ }^{1}$ \\ Lanjong Foundation, Kutai Kertanegara
}

\begin{abstract}
ABSTRAK
Artikel ini membahas proses penciptaan naskah drama Ambu Hawuk. Naskah ini diadaptasi dari cerita lisan dan mitologi lokal yang berkembang di daerah Sunda. Cerita lisan dikumpulkan melalui wawancara mendalam dengan para informan yang mewakili berbagai versi. Setidaknya terdapat enam versi tradisi lisan mengenai tokoh ini, yaitu versi Cikawungading, Manonjaya, Cianjur, Sukaraja, Parungponteng, dan Galunggung. Dari keenam versi tersebut terdapat variasi dan kesamaan. Naskah ini mencoba membangkitkan kembali semangat feminisme dalam peristiwa-peristiwa yang dijalin dalam legenda Ambu Hawuk. Sistem patriarki masyarakat Sunda lebih sering memandang perempuan sebagai sebuah kaum yang memiliki keterbatasan dibandingkan dengan kaum laki-laki. Cerita ini menggambarkan seorang perempuan yang dianggap berada di belakang laki-laki dan menjadi bayangbayang seorang laki-laki, muncul menjadi seorang pemimpin.
\end{abstract}

Kata kunci: Ambu Hawuk, naskah drama, tradisi lisan.

\section{ABSTRACT}

The Creating Process of Drama Script Ambu Hawuk Based on the Oral Tradition and the Gender Perspective. This article discusses about the creating process of the drama script Ambu Hawuk. This script was adapted from the oral story and the local mythology developed in Sunda. This oral story was compiled through the intensive interview with some sources of information that represented many kinds of versions. There are six versions of the oral tradition talking about this character, namely: the version of Cikawungading, Manonjaya, Cianjur, Sukaraja, Parungponteng, and Galunggung. Of those six versions, there are varieties and similarities. This script tries to develop feminism spirit on some interrelated events in Ambu Hawuk legend. From the perspective of Sundanese point of view on the patriarchy system, women are regarded as God's creature who have more basic physical and mental limitations than men. This story describes a woman who is regarded as a person behind the man's existence and becomes the man's shadow; but soon afterwards, she becomes a leader.

Keywords: Ambu Hawuk, Drama Script, Oral Tradition

\section{Pendahuluan}

Pelestarian seni budaya berbasis kearifan lokal dimaknai sebagai usaha pemeliharaan dan pengembangan seni budaya tradisi masyarakat pendukungnya. Nilai-nilai tradisi masyarakat terwujud dalam berbagai bentuk, di antaranya cerita-cerita lisan yang merupakan bagian dari folklor dan menjadi sebuah warisan budaya (Danandjaja,2002:5). Salah satu cerita lisan berbasis kearifan lokal adalah Ambu Hawuk, legenda dari Tatar Priangan. Tradisi lisan dapat menjadi dasar bagi penciptaan seni budaya baru yang berkaitan dengan usaha melestarikan seni budaya Sunda. Para leluhur budaya Sunda telah memberi tuntunan 'Hana nguni hana mangke, tan hana nguni tan hana maengke. Aya nu baheula_ heunteu ma baheula_henteu ta ayeun yang berarti bahwa ada masa lalu maka ada masa sekarang, tiada pendahulu, apa jadinya masa sekarang, karena ada masa lampau maka ada masa kini.

Menurut Rusyana (2008: 6) terdapat beberapa alasan untuk melestarikan tradisi seni budaya Sunda, yaitu pertama, seni tradisi Sunda merupakan bagian dari budaya Sunda serta mempunyai unsur-unsur yang saling terhubung; kedua, seni tradisi Sunda merupakan mencerminkan budaya Sunda secara keseluruhan; ketiga, seni tradisi Sunda dalam satu unsur budaya Sunda mempunyai kaitan yang erat dengan unsurunsur budaya lainnya. Pelestarian tradisi lisan tidak hanya dilakukan dengan jalan menghafal cerita, menyimpan artefak tradisi lisan tersebut, atau menjadikannya sebagai teks tulis. Tradisi lisan memiliki potensi yang dapat diwujudkan dengan

1 Alamat korespondensi: Lanjong Foundation. Jalan Kramajaya No. 59 A Mangkurawang, Tenggarong, Kutai Kertanegara. Telepon: 0852210 22228. E-mail: ab_asmarandana@yahoo.com. 
berbagai pengembangan, salah satunya adalah dengan membentuknya sebagai sebuah karya seni drama dan seni pertunjukan teater.

Berdasarkan hal tersebut penulis mengangkat legenda Ambu Hawuk yang tersebar di hampir seluruh tatar Parahiangan. Ketertarikan penulis pada cerita ini pada awalnya ketika mendengar legenda tersebut menyebar luas di daerah Galunggung dan di daerah Cikawunggading, Kabupaten Tasikmalaya. Ambu Hawuk menurut sebagian versi bernama Siti Mundigar. Beberapa versi menyebut cerita ini berasal dari Kanoman Cirebon. Ada juga yang mengatakan bahwa cerita ini berasal dari Sumedang, putri dari pangeran Kornel. Semua kisah memiliki perbedaan namun semua sepakat bahwa Ambu Hawuk adalah tokoh perempuan Sunda yang gagah perkasa.

Tiga watak utama keperkasaan Ambu Hawuk yang menarik dalam konteks perjuangan perempuan, yaitu: pemberontak, berani, dan cerdas. Sebagai sosok perempuan, Ambu Hawuk dikenal dengan cita-citanya tentang kemerdekaan. Ia memiliki masa lalu yang menyedihkan. Selain itu, ia juga dikenal melakukan pemberontakan pada kaum penguasa di zamannya. Perjuangannya tidak saja menyentuh persoalan kesetaraan jender, namun juga tentang pengorbanan diri. Karakter yang menarik dari diri Ambu Hawuk tersebut menginspirasi penulis untuk menulis sebuah naskah drama dengan judul seperti namanya, yaitu Ambu Hawuk.

Legenda Ambu Hawuk adalah legenda tentang perjuangan perempuan. Perempuan berjuang melawan sistem dan stuktur yang dikuasai oleh laki-laki. Adanya gerakan feminis dalam cerita Ambu Hawuk di Tasikmalaya merepresentasikan perjuangan kesetaraan perempuan melawan sistem dan stuktur kehidupan masyarakat di Tasikmalaya. Penulisan naskah drama dan pertunjukan teater feminis cenderung menggunakan kritik sosial feminis bagi pengelolaan penulisan drama, praktik berteater, dan kajian seni teater (Yudiaryani, 2002:215). Untuk itulah penciptaan naskah drama ini dilakukan dengan cara melacak jejak cerita perjuangan tokoh perempuan $\mathrm{Ambu}$ Hawuk yang berkembang di selatan Tasikmalaya, tepatnya di Desa Cikawungading, Kecamatan Cipatujuh. Tidak sekedar perjuangannya tetapi juga pandangan masyarakat terhadap dampak perjuangannya. Di Desa Cikawungading terdapat artefak berupa nisan di dekat sungai Cilangla. Ayat Rohaedi (dalam Soemardjo, 2003:288) mengatakan kesaksiannya setelah berkeliling Jawa Barat, terutama di situs-situs sejarah, bahwa banyak makam tua yang merupakan makam kosong saja. Kemungkinan makam-makam itu hanya mitos belaka dan bukan fakta historis. Hal tersebut diperkuat oleh Robert Wessing (dalam Soemardjo, 2003:289), antropolog Amerika yang banyak berbicara tentang budaya Sunda masa lalu. Wessing mengatakan bahwa adanya sebuah legenda dari sebuah kampung akan menunjukkan asal usul kampung tersebut.

\section{Cerita Lisan Ambu Hawuk}

Cerita lisan Ambu Hawuk memiliki keunikan dengan banyaknya versi cerita rakyat yang ada. Cerita-cerita tersebut memiliki tafsir yang berbeda-beda namun tetap menggunakan $\mathrm{Ambu}$ Hawuk sebagai tokoh sentral cerita tersebut. Penulis berhasil mengumpulkan beberapa kisah yang didapat dari hasil wawancara dengan salah satu juru kunci di makam Ambu Hawuk di Cipatujah dan beberapa narasumber dari Manonjaya, Galunggung, serta para budayawan Sunda, seperti Raden Juha dan Dedi Sambas.

Berikut ini adalah beberapa versi cerita lisan Ambu Hawuk yang berhasil dikumpulkan.

\section{a. Versi Cikawungading}

Versi ini diperoleh melalui wawancara dengan Abah Apri, seorang juru kunci Ambu Hawuk di Cikawungading, Cipatujuh, Tasikmalaya. Berdasarkan wawancara diperoleh cerita sebagai berikut.

Kacariosken Ambu Howuk nyaeta isteri nu geulis nu asalna di Kasepuhan Cirebon di candak ka Sukapura ku bojona duka namina mah saha... tina jaman pami teu lepat mah Kanjeng Daleman di Sukapura, Ambu Howuh caket sareng Syeh Abdul Muhyi ti Pamijahan, tah kapungkur saur pun aki nuju Aki Saumur 12 tahun mereun saurna mah di daerah Cijoho sukaraja Ambu Howuk waktos ngalalana Ambu Hawuk seur ngobatan jalma nu galering contona nu pateuh tulang na ngobabatan nana ku kasaktianana, dugi anjenaa di kenal dukun atawa tabib, kela tah da ieu carios teh leres. Saur pun bapakAmbu Hawuk teh kagungan najar hoyong 
mencit sapi bodas, kumargi anjenan tos nyepitan putrana, tah, harita peraturan wahos eta teu lcenging mencit sapi bodas teh. Dukakunaon teu kengingna mah, dugi anjena Ambu Hawuk di tewak terus we di bui ku Kanjeng Dalem Sukapura, mung anehna angkoh Ambu Hawuk teh di penjara tapi waragana ge aya ti lyuar panjara, mereun ku ka rosaan nana kumargi kitu Ambu Hawuk diangkat jadi pendekar di wilayah kidul ku kerajaan Sukapura kanggo benteng tina serbuan karajaan galuh jeung pancatengah. Ambu Hawuk anakna 12 urangsakabeh putra putrina di pasiban hiji gunung. Ayena di dieu aya makamna Ambu Hawukdi Cikawungading. Tapi aki oge pernah ngadangu cenah mah oya oge latburanaann di Cianjur. Ah teuing da jalama bareto mah genoning sararakti i.

(Diceritakan, Ambu Hawuk adalah seorang perempuan yang berparas cantik. Dia berasal dari kasepuhan Cirebon yang di bawa ke Sukapura oleh suaminya yang bernama... pada jaman Kanjeng Daleman di Sukapura Ambu Hawuk, dikenal dekat dengan Syeh Abdul Muhyi dari Pamijahan, di daerah Cijoho Sukaraja. Pada saat melakukan perjalanan Ambu Hawuk banyak mengobati orang yang sakit dengan kesaktiannya, sehingga dia dikenal sebagai dukun atau tabib. Suatu hari Ambu Hawuk bernadzar akan menyembelih sapi putih sebagai rasa syukur khitanan anaknya. Namun peraturan masa itu tidak diperkenankan menyembelih sapi putih, sehingga Ambu Hawuk ditangkap dan dipenjara oleh Kanjeng Dalem Sukapura. Suasana menimbulkan keganjilan, karena Ambu Hawuk ada di dalam penjara, tetapi di saat yang sama ia juga ada di luar penjara. Berkat kesaktiannya, Ambu Hawuk diangkat menjadi pendekar di wilayah kidul oleh kerajaan Sukapura sebagai benteng dari penyerbuan kerajaan Galuh dan Pancatengah. Ambu Hawuk berputra 12 semua anaknya di wariskan satu gunung, dan setiap gunung bernama putra putri Ambu Hawuk, peninggalannya berupa makam di daerah Cikawungading).

\section{b. Versi Cikawungading II}

Makam Uyut Cibengkok alias Ambu Hawuk adalah versi menurut Aki Karma, satu dari dua juru kunci di makam Ambu Hawuk. Cerita tersebut diperoleh dari hasil wawancara penulis dengannya yang kala itu dilakukan sambil melafalkan ritual pemanggilan roh Ambu Hawuk. Namun, upacara ini tidak boleh diabadikan lewat rekaman baik audio maupun visual.

\section{c. Versi Manonjaya}

Versi Manonjaya diperoleh memalui wawancara dengan Maman, juru kunci makam Raja Sukapura di Manonjaya, Tasikmalaya. Berikut hasil wawancara dengan Maman.

Kieu ari ceuk sakol mah, tapi ampun paralun da bapak ge teu kantos terang saha Siti Mundigar teh, komo dipatula talikeun sareng Ambu Hswuk, da saterang bapak mah Siti Mundigar mah ti Sumedang, putrana Pangeran Kornel, ku kasaktianana cenahmah ku pangajen Sukapura Siti Mundigar di subunken ka Sukapura kanggo ngajagi kamanan. Da saurna mah ku sakti sakti na. Siti Mundigar mun kaluarga karajaan nuju moro nuju ngaherap. Terus we siti Mundigar teh emokwe, da etamah, cai ti Citarum teh erun siga nu di bendung.. teras socana saurna tiasa melong anu jauh dugi tempat ieu dibamian manonjaya nyaeta panon anu jaya anu hebat. ngan dasar urang Sunda panon ge jadi manon. Teu kacariosken Siti Mundigar teh gaduh nenehan Ambu Hawuk.

(Siti Mundigar seorang bangsawan putri dari Pangeran Kornel dari Sumedang. Dia sangat sakti, sehingga dibawa oleh para pembesar Sukapura ke tanah Priangan untuk ikut menjaga keamanan. Kesaktiannya bisa membendung Citarum dengan hanya melakukan duduk emok lalu air sungai itu berhenti. Juga kesaktian matanya yang bisa melihat jauh, hingga daerah itu bernama Manonjaya. Panon berarti mata dalam bahasa Indonesia dan Jaya dimaknai sakti sehingga Panonjaya adalah mata yang sakti, kemudian nama Panonjaya menjadi Manonjaya karena pelafalan lidah Sunda. Namun demikian, tidak terceritakan kalau Siti Mundigar itu menjadi Ambu Hawuk.

\section{d. Versi Cianjur}

Versi ini diperoleh melalui wawancara dengan Pak Juha,seorang Budayawan Sunda. Menurutnya, setelah berperang di Batavia melawan VOC, Ambu Hawuk berjalan menuju Cianjur. Pada peperangan tersebut konon para pendekar dipukul mundur oleh Belanda karena terjadi komunikasi 
dan kerjasama yang tidak baik di antara mereka. Di Cianjur juga ada yang mengakui bahwa Ambu Hawuk tinggal di sana. Ia meninggal dan dimakamkan di Cibungur, Cianjur.

\section{e. Versi Sukaraja}

Versi ini diperoleh memalui wawancara dengan Bapak Dedi Sambas di Tasikmalaya. Menurutnya Ambu Hawuk adalah perempuan sakti yang kakinya berwarna kelabu dan kotor. Ia dikenal juga sebagai seorang perompak di Laut Kidul. Hasil dari merampok diberikan pada orang-orang yang tidak mampu. Ambu Hawuk hidup di jaman Belanda sekitar abad ke-17. Para serdadu Belanda menjulukinya dengan 'Setan Dari Selatan' karena mereka sulit menangkap Ambu Hawuk. Dikabarkan pula bahwa Ambu Hawuk adalah sahabat Syeh Abdul Muhyi.

\section{f. Versi Parungponteng}

Versi ini diperoleh melalui wawancara dengan seorang informan yang masih memiliki garis keturunan dengan Ambu Hawuk di Parungpoteng, Cibalong. Dalam versi ini diceritakan bahwa di Kampung Kidul ada peristiwa yang menggemparkan karena ada perempuan yang mampu menumbangkan pohon Kawung untuk dijadikan pancuran air. Dia duduk di pucuk pohon itu dengan kakinya yang kelabu dan kotor. Dialah Ambu Hawuk yang sakti. Ambu Hawuk adalah perampok perempuan yang baik hati pada orang miskin. Ia dikenal juga sebagai tabib. Suatu saat di Cijoho ketika perjalanannya dari selatan menuju Sukapura, dia bertemu dengan orang lumpuh. Dia hanya mengusap bagian yang sakit, orang tersebut langsung bisa berdiri dan berlari. Ambu Hawuk dikenal pula sebagai penasehat kerajaan Sukapura.

Hasil wawancara dan ritual di Galunggung bersama bapak Soma sebagai berikut.

"Ek noon tatanya eyang? Ke we peuting sadiaken we hayam bodasbuntutna kasiran, 7 endog hayam, kembang rokok jeng sajabanajang sasaji? Ke peuting urang ka kswah?"

("Mau apa bertanya tentang eyang? Nanti malam siapkan saja sesaji berupa ayam putih dengan ekor kecil, tujuh buah telor ayam, bunga dan rokok ke kawah Galunggung").
Setelah menyiapkan segala yang diminta dengan syarat tidak direkam melalui apapun penulis hanya diminta mengingat segala yang diucapkan penjaga makam dan segala yang dilihat penulis. Di puncak Gunung Galunggung ketika ritual dilakukan terlihat bapak Soma berdoa lalu berdialog dalam kondisi trance sebagai berikut.

"alus jang tibatan ngan ngaraco alus tah lengkah teh, kieu ari caritanamah. Tahun 1011 Ambu teh dulur deked jeng sempak waja. Anjena wanoja rosa da tuh di ditu nepi kadieu ngan ngajleng we.

("bagus Jang. Daripada tidak benar lebih bagus langkah yang kamu tempuh, begini ceritanya. Tahun 1011 Ambu itu saudara dekat dengan Sempak Waja. Dia perempuan sakti, coba lihat dia lompati dua bukit itu”)

Selanjutnya tidak begitu sangat jelas Bapak Soma terlempar ke sana-ke mari sebelum terduduk dan tertunduk. Dia meminta maaf ritual tidak bisa dilanjutkan karena ada sesuatu yang tidak boleh diungkapkan. ${ }^{2}$

\section{g. Versi Galunggung}

Dari prasasti yang ditemukan di Geger Hanjuang Tasikmalaya, menurut penuturan Ki Soma, diketahui ada nama seorang batara perempuan, satu satunya di alam ini yaitu Batari Hyang, yang pada tahun 1111 mengubah bentuk kebataraan menjadi kerajaan, kerajaan Galunggung. Enam orang batara yang memerintah sebelum Batari Hyang bernama Batara Sempak Waja, Batara Kuncung Putih, Batara Kawindu, Batara Wastuhayu, Batara Gunawisesa. Batara Gunawisesa adalah kakak Batara Kuncung Putih. Batara termuda adalah Wahyu Cakraningrat. Ambu Hawuk dikenal dengan nama Batara Kuncung Putih, Nyi Mas Garsih. Ambu rawuk adalah perempuan yang penuh ambisi dan memiliki bakat dalam ilmu sihir. Ia bisa meloncat satu kali dengan dua tiga bukit ia lalui. Suatu saat datang seorang ahli ilmu sihir dari Cirebon. Dikisahkan mereka mengadu ilmu dan Ambu Hawuk kalah lalu terusir dari Galunggung.

2 Hasil ritual di kawah Galunggung pada tanggal 6 April 2007. 


\section{Penciptaan Naskah Drama Ambu Hawuk: Dari Lisan Menjadi Tulisan}

Beberapa versi cerita Ambu Hawuk di atas menginspirasi penulis untuk mencipta sebuah naskah drama yang memiliki ide tentang keperkasaan perempuan. Judul naskah drama yang ditulis adalah Ambu Hawuk sesuai dengan nama tokoh utamanya. Pilihan tersebut dipakai untuk menegaskan arti pentingnya tokoh perempuan Ambu Hawuk. Hal ini menjadi penting artinya karena perempuan mengurus kehidupan di dalam rumah, perempuan menenun seluruh pakaian keluarga, perempuan (yang sudah bersuami) ikut aktif di luar rumah. Itulah sebabnya rumah itu sendiri di dalam kosmologi Sunda berarti perempuan. Perempuan adalah lokalitas, rumah, dan kehidupan. Rumah adalah milik perempuan, lelaki hanya membangun rumah atau sebagai pemakai rumah (Soemardjo,2003:281). Selain mengenai kekuasaan dan pengkhianatan, cerita Ambu Hawuk juga menampilkan cerita tentang seorang pemimpin perempuan bersama dengan mimpi-mimpi dan keterpurukannya, serta pengkhianatan terhadap cita-cita dan dirinya. Ayat Rohaedi (2002) menyimpulkan bahwa:

"...di masyarakat Sunda, baik yang tradisional maupun masyarakat masa silam, perempuan memiliki kedudukan dan peran penting, bahkan kadang kala terkesan bahwa kedudukan perempuan itu demikian penting, sedang laki-laki muncul sebagai pelengkap untuk mendukung kehormatan dan kemuliaan perempuan”.

Kesimpulan itu menegaskan bahwa nilainilai lama dalam suatu masyarakat terus hidup di tengah-tengah perubahan nilai-nilainya. Dialog di adegan 15 dalam lakon Ambu Hawuk terlihat ketika Ambu berhadapan dengan pengikut setianya, Somahita, yang berkhianat.

\begin{abstract}
"kamu baik sekali Soma...Soma tadi kamu bilang bagian laki laki adalah menjaga... dan perempuan tidur ? itulah kesalahan laki laki Soma, sehingga membuat para perempuan bermimpi...Alam yang subur meninabobokan perempuan Sunda sampai terlena, hingga tidak perlu bekerja keras. Alam sudah menjamin kelangsungan, kehidupan mereka. Cukup lelaki yang bekerja di ladang atau sawah, sementara perempuan di rumah mengurus dan merawat anak, mempercantik diri, itu kelak yang akan terjadi... hanya karena kalian salah sangka, bahwa tenaga adalah segalanya....Ingat Soma, perempuan Sunda itu otak dari tubuh yang bisa meredakan perang...kelak tatar Sunda jaya kala mangsa di cekeul ku hiji wanoja..."
\end{abstract}

Jelas dalam dialog di atas, Ambu Hawuk diposisikan oleh penulis sebagai perempuan yang mempraktikkan secara politis perlawanan terhadap tradisi dominasi sistem patriarki. Perempuan dalam masyarakat Sunda lama memang menduduki tempat terhormat karena adanya pemahaman nilai-nilai asal orang peladang dan masyarakat Sunda. Ladang dalam masyarakat Sunda disebut huma. Fokus pada perladangan inilah yang menjadi struktur nilai-nilai kualitas dari dalam batin, menjadi nilai-nilai ideal dalam sistem pengetahuan ladang.

Patrice Pavis (dalam Yudiaryani, 2009:111) menyebutkan dua faktor yang harus diperhatikan dalam membentuk tranformasi atau pelestarian tradisi lisan menjadi tradisi tulis, yaitu rekontruksi rantai pertemuan antara budaya sumber (si pengirim, produser, seniman) ke budaya target (si penerima, konsumen, pembaca, penonton). Gambar di bawah ini menunjukkan bagaimana pertemuan antara budaya sumber dan budaya target melalui naskah drama atau melalui mise en scène pertunjukan teater. 


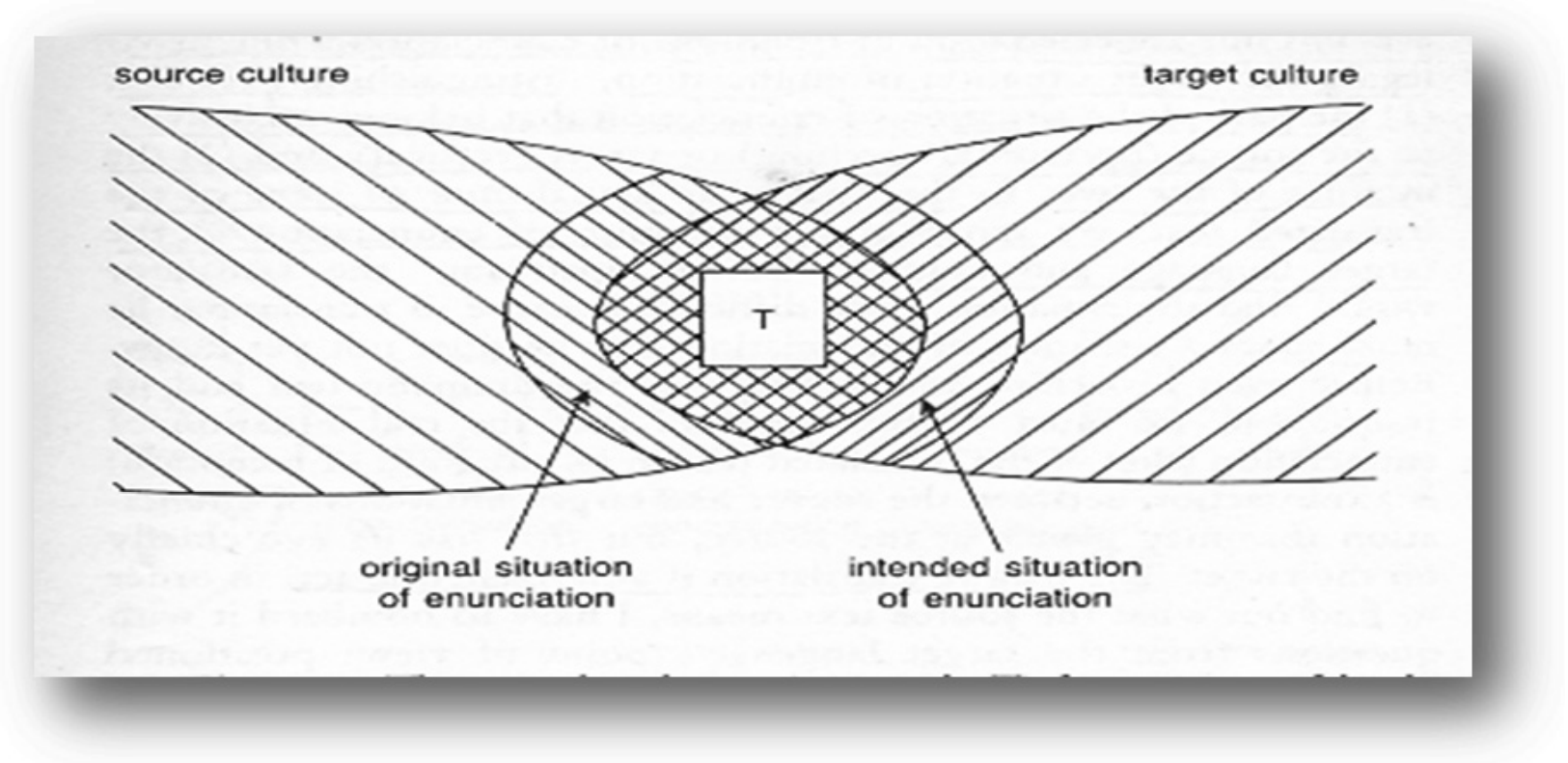

Wilayah (T) pada gambar di atas merupakan wilayah pertemuan antara situasi yang dikehendaki pengirim dengan situasi yang dikehendaki penerima. Teori tranformasi budaya lisan menjadi budaya tulis didefinisikan sebagai sistem penandaan yang hadir secara bersamaan atau berlawanan dalam ruang dan waktu pembacaan oleh pembaca. Demikian juga ketika budaya tulis akan ditransformasikan ke dalam budaya audio visual/panggung pertunjukan oleh seniman teater mengharuskan kehadiran sebuah ruang pertemuan yang disebut dengan mise en scène. Dengan kehadiran teori mise en scène maka teori ini berhasil membedakan istilah 'teks' yang berarti teks drama dan 'teks' yang berarti teks pertunjukan. Teks drama merupakan naskah verbal yang dibaca dan didengar dalam pertunjukan. Teks ini merupakan teks yang ditulis sebelum pertunjukan hadir. Teks pertunjukan merupakan semua yang dicipta secara audio visual di atas panggung. Pavis menyebutkan pula dua wilayah yang harus diperhatikan dalam membentuk mise en scène, yaitu budaya sumber dan budaya target (Pavis, 1992:185-207).

Naskah drama Ambu Hawuk mengangkat ide dasar mengenai tokoh perempuan berhadapan dengan kekuatan penguasa dan pengkhianatan. Perjalanan seorang perempuan yang mengalami peristiwa nahas ketika rumah dibakar, ditinggal mati ibu, bapak dan saudara-saudaranya. Ia mengembara ke seantero negeri, menuruni lembah curam, memasuki hutan belantara, dan menghadapi ganasnya hujan dan panas.
Ia harus menghadapi kekuatan penguasa yang begitu besar. Ia mencoba kemampuan dirinya dengan melawan ketidakadilan. Ia berhasil menemukan jati dirinya dengan melupakan dendam dan melawan kesewenang-wenangan. Gambaran perjalanan tersebut dipenuhi simbol dan cerita-cerita lisan di sekitarnya. Pahit getirnya pengalaman seseorang adalah sebuah pintu untuk mengenali dunia bawah sadarnya, dan agar mampu kembali ke alam realita dengan memiliki vitalitas baru. Perjalanan pencarian jati diri Ambu Hawuk adalah simbol yang memiliki keterkaitan dengan realita perjalanan manusia menuju revitalisasi kehidupannya.

Penciptaan drama Ambu Hawuk ini memperlihatkan posisi perempuan yang sering diperlakukan sebagai kaum yang tidak mampu memiliki kemampuan melebihi kaum lakilaki. Tokoh Ambu Hawuk merepresentasikan tentang perjuangan seorang perempuan yang dalam segala keterbatasan justru mampu memimpin perjuangan melawan kesewenangwenangan penguasa yang notabene adalah lakilaki. Ambu Hawuk sendiri dalam bahasa Sunda berarti perempuan yang memiliki kaki yang kelabu dan kotor, tetapi justru di situlah senjata pamungkasnya, yaitu tendangan kakinya. Dengan kakinya yang kelabu dan kotor itulah Ambu Hawuk berjuang untuk menegakkan keadilan dan memberi kesejahteraan rakyat. Tepatlah pendapat bahwa perempuan adalah 'tiang' kehidupan yang mampu menegakkan dunia. 


\section{Sinopsis Naskah Drama Ambu Hawuk Berperspektif Jender}

Ambu Hawuk adalah perempuan cantik yang memiliki kharisma yang luar biasa. Awal mula cerita ini dimulai dari mimpi Kanjeng Dalem tentang sosok perempuan yang melepas mahkotanya. Mimpi itu datang tiga kali berulang setiap malam dalam tidurnya. Hal tersebut membuat Kanjeng Dalem merasa cemas dan ingin segera membakar perkampungan sesuai dengan petunjuk mimpinya bahwa akan datang seorang perempuan dari perkampungan tersebut yang akan mengusik kekuasaannya. Akhirnya sesuai dengan perintah Kanjeng Dalem semua kampung dibakar habis tidak tersisa. Hanya ada satu anak yang selamat, yaitu Ambu Hawuk kecil yang ditolong oleh seorang berjubah putih.

Setelah insiden tersebut Ambu Hawuk pun dibekali ilmu kanuragan oleh sosok yang menyelamatkannya. Setelah dirasa cukup, Ambu Hawuk pun dilepas untuk kemudian melakukan pengembaraan. Setelah waktu berjalan, Ambu Hawuk mulai terkenal dengan kesaktian dan kemurahan hatinya yang suka menolong dan juga mengobati kaum miskin. Ambu Hawuk mulai melihat kesewenang-wenangan kekuasaan yang dilakukan oleh Kanjeng Dalem. Hal itulah yang membuat Ambu Hawuk bersama beberapa pengikutnya melakukan perampokan kepada orang-orang kaya lalu hasil rampokan tersebut dibagikan kepada orang-orang miskin.

Kabar perampokan yang dilakukan oleh Ambu Hawuk akhirnya terdengar juga oleh Kanjeng Dalem. Ia segera melakukan segala cara untuk menghentikan aksi Ambu Hawuk dan pengikutnya. Semua hal telah dilakukan Kanjeng Dalem, termasuk mengumpulkan para jawara untuk memberantas kelompok Ambu Hawuk, tetapi tidak pernah berhasil. Hingga salah satu pengikut dari Ambu Hawuk yaitu Somahita melakukan pengkhianatan dengan akal bulusnya memberi minuman jahe hangat yang di dalamnya ada racun untuk membuat Ambu Hawuk lengah, dan mengambil selendang merah. Selendang inilah yang menjadi senjata yang merupakan kekuatan sekaligus kelemahan dari Ambu Hawuk. Sampai pada akhirnya akibat dari kecurangan dan keburukan hati dari Somahita menjadikan dirinya sendiri hancur oleh sikap dan perilakunya.

\section{Naskah Drama Ambu Hawuk}

Drama Ambu Hawuk secara keseluruhan terdiri dari Sembilan belas adegan yang tersusun sebagai berikut.

\section{Adegan I}

Rajah Bubuka merupakan semacam doa minta perlindungan dan keselamatan. Berikut ini adalah isian dari rajah tersebut.

lain ngusik ula mandina, lain ngahudang macan turunna,lain ngungkit nu kamari lain ngungkap nu baheula, rek ngaguar tutungkusan karuhun amit ampun nya paralun, Kuring rek nyukcruk galur, Iatlarak rek diajar ngidung, Meulah carita Nya ngidung carita lisan, Ngahudang carita wayang, Nyilokakaeun laku nu rahayu Mapay carita baheula, Cuang buka cupumanikna, Cuang guar mutimana Keur urang jeung turunan urang, ka luruh neda papayung papayung nu maha Agung ka handap neda pang raksa, pang raksa nu maha Kawasa, kaler kulon kidul wetan mugi di aping di jarring, ti luhur ti karubun ti buyut ti nini aki, nu nurunkeun kabudayaan, ieu abdi sadayana, seja ngaraksa mupusti, seja ngaraksa mupusti, amit kanu mangku lembur, kanu nyungsi dinu sepi nu keur genah tumaninah, bisi ka usik keur calik, kalangkah kalliliwatan neda agung nya haksami, ka langkah kal liliwatan, neda agung nya haksami

(bukan niat mau mengganggu bukan niat membangunkan harimau tidur, bukan mau mengungkap hal yang kemarin, bukan mau mengungkap masalah yang lampau, tapi hendak membuka peninggalan orang terdahulu. Mohon ampun kami mau menapak tilas sebab mau belajar berkidung membuka cerita dengan ngidung cerita lisan membuka cerita wayang menyimbolkan kehidupan yang agung dengan mengikuti cerita lama. Kita buka misterinya buat kita dan turunan kita. Ke atas minta pertolongan yang agung ke bawah minta dijaga oleh yang maha kuasa. Utara selatan timur barat semoga dilimpahkan pada orang orang yang telah mewariskan kebudayaan ini. Kita semua mau menjaga, melestarikan. Salam kepada pemangku desa. Pada yang mendiami tempat sepi yang sedang tenang, kalau terusik sedang duduk terlangkahi dan terlewati mohon maaf yang sebesar besarnya). 


\section{Adegan II}

Penggambaran mimpi Kanjeng Dalem tentang mahkotanya yang dilepas oleh Ambu Hawuk digambarkan dengan tarian dan dialog Kanjeng Dalem:

Mimpi ini berulang ..seseorang dengan kaki berwarna abu abu ..dari selatan ia datang, seorang perempuan melepas mahkotaku... ini tidak bisa dibiarkan

\section{Adegan III}

Seorang nenek sedang bercerita kepada cucunya. Cerita yang diceritakan adalah cerita yang sudah turun temurun diwariskan kepadanya, yaitu tentang tokoh perempuan Sunda, Ambu Hawuk.

Dialog Nini dan Incu :

\begin{tabular}{|c|c|}
\hline Nini & : Ya sudah nini akan ngadongeng. \\
\hline & Dongeng apa ya? \\
\hline & Oh..dongeng Sang kancil dan timun \\
\hline Incu & $\begin{array}{l}\text { : Incu sudah dengar tujuh kali, } \\
\text { Ni.klise }\end{array}$ \\
\hline Nini & $\begin{array}{l}\text { : Kalau begitu, rnrnrn, Sangkuriang } \\
\text { dan Dayang Sumbi. }\end{array}$ \\
\hline Incu & $\begin{array}{l}\text { : Kemarinkan sudah.. yang ceritanya } \\
\text { perahu terbalikkan, Ni? }\end{array}$ \\
\hline & $\begin{array}{l}\text { Yang ibunya jatuh cinta sama } \\
\text { anaknya, kan? }\end{array}$ \\
\hline Nini & $\begin{array}{l}\text { : Salah.. anaknya yang jatuh cinta } \\
\text { sama ibu }\end{array}$ \\
\hline
\end{tabular}

\section{Adegan IV}

Dengan dipenuhi rasa takut dan khawatir, Kanjeng Dalem memerintahkan patihnya untuk segera membumihanguskan sebuah desa dengan mengirimkan pasukan berkuda yang lengkap dengan senjatanya. Terbaca dalam dialog berikut ini :

Kanjeng Dalem

: Kirim pasukan berkuda lengkap dengan senjata. Undang para Jawara untuk memberantas perempuan itu. Pakai gerombolan kidul saja, suruh bumi hanguskan wilayah selatan dan imbalannya adalah tanah jadi milik mereka.

Tapi dampaknya kelak. Mereka bisa menjadi ancaman serius bagi kita. Ini hanya strategi.

Maksudnya. Kita hanya mengasih janji. Setelah mereka membumi hanguskan wilayah selatan. Kita kirim pasukan berkuda yang lengkap senjatanya

Dan atas nama rakyat kita sudah menumpas kejahatan yang paling kita sukai

Patihhhh...

\section{Adegan V}

Adanya serangan dari pihak Kanjeng Dalem untuk menghancurkan sebuah desa yang digambarkan dengan pembakaran rumah dan tarian obor.

\section{Adegan VI}

Muncul juru pantun sebagai pewarta. Ia mengisahkan bumi tempat berpijak sudah penuh dengan kerusakan. Juru pantun melontarkan pantun dengan gaya pantun Sunda dan nyanyian.

\section{Adegan VII}

Ambu kecil merasa kehilangan emak dan bapaknya, rumah dan tanahnya telah diratakan.

\section{Adegan VIII}

Nyai berdiri di atas batu karang sambil bersenandung, karena kampung halamannya telah dibinasakan.

Isi senandung Ambu:

"mereka yang telah membinasakan kampung halamanku?... Mereka yang telah membunuh yang bergerak di sini?...Mereka yang menantang matahari"

\section{Adegan IX}

Kelompok Topeng telah berhasil membumihanguskan sebuah desa dari kidul sesuai perintah Kanjeng Dalem dengan imbalan yang menjanjikan.

\section{Adegan X}

Nenek kembali melanjutkan ceritanya. Sampai akhirnya cucunyalah yang diculik oleh para topeng, sehingga ada aksi protes dari cucunya 
bahwa neneknya harus menghapus sebagian ceritanya karena tidak mungkin jagoannya mati.

\section{Adegan XI}

Konspirasi Kanjeng Dalem berjalan lancar. Kanjeng Dalem menerima laporan dari patihnya bahwa kabar dari Cikawungading dan Wadana dari Kidul sudah diterima. Mereka sudah diperintahkan untuk segera lapor tetapi belum juga datang. Ki Lurah kabarnya ikut terbunuh, desa di kidul dibakar rata. Senanglah Kanjeng Dalem tinggal siasat kedua dia harus menumpas gerombolan topeng untuk meyakinkan rakyat bahwa pemerintahan berjalan lancar dan tegas dengan menghukum yang bersalah.

\section{Adegan XII}

Nenek bercerita kepada cucunya bahwa Ambu Hawuk yang seperti Robin Hood telah diselamatkan dan berdiam di Galunggung, belajar berbagai ilmu serta pintar mengobati. Selain itu, Ambu Hawuk juga merampok orang-orang kaya yang kemudian dibagikannya kepada orang miskin.

\section{Adegan XIII}

Muncul kembali juru pantun sebagai pewarta dan berkidung bahwa ada pertempuran besarbesaran antara kelompok Ambu Hawuk dan Kanjeng Dalem.

\section{Adegan XIV}

Ambu Hawuk duduk di atas batu karang dan mengadu kepada laut bahwa lautlah sebagai tempatnya mengadu segala keluh kesahnya.

\section{Adegan XV}

Nenek menceritakan kepada cucunya bahwa di dalam cerita Ambu Hawuk ada seorang pengkhianat.

\section{Adegan XVI}

Soma mencoba merayu Ambu Hawuk bahwa di dalam kelompoknya ada seorang pengkhianat. Soma sendirilah pengkhianat itu dan ternyata Soma jatuh cinta kepada Ambu Hawuk.

\section{Adegan XVII}

Ambu mengetahui akal bulus Soma, sehingga Ambu mengutuk Soma.

\section{Adegan XVIII}

Tinggallah Ambu sendiri, sepi dan tenang.

\section{Adegan XIX}

Selanjutnya, muncul Juru pantun dan menutup cerita ini. Sebelum gelap tampak cucu tertidur pulas di pangkuan nenek.
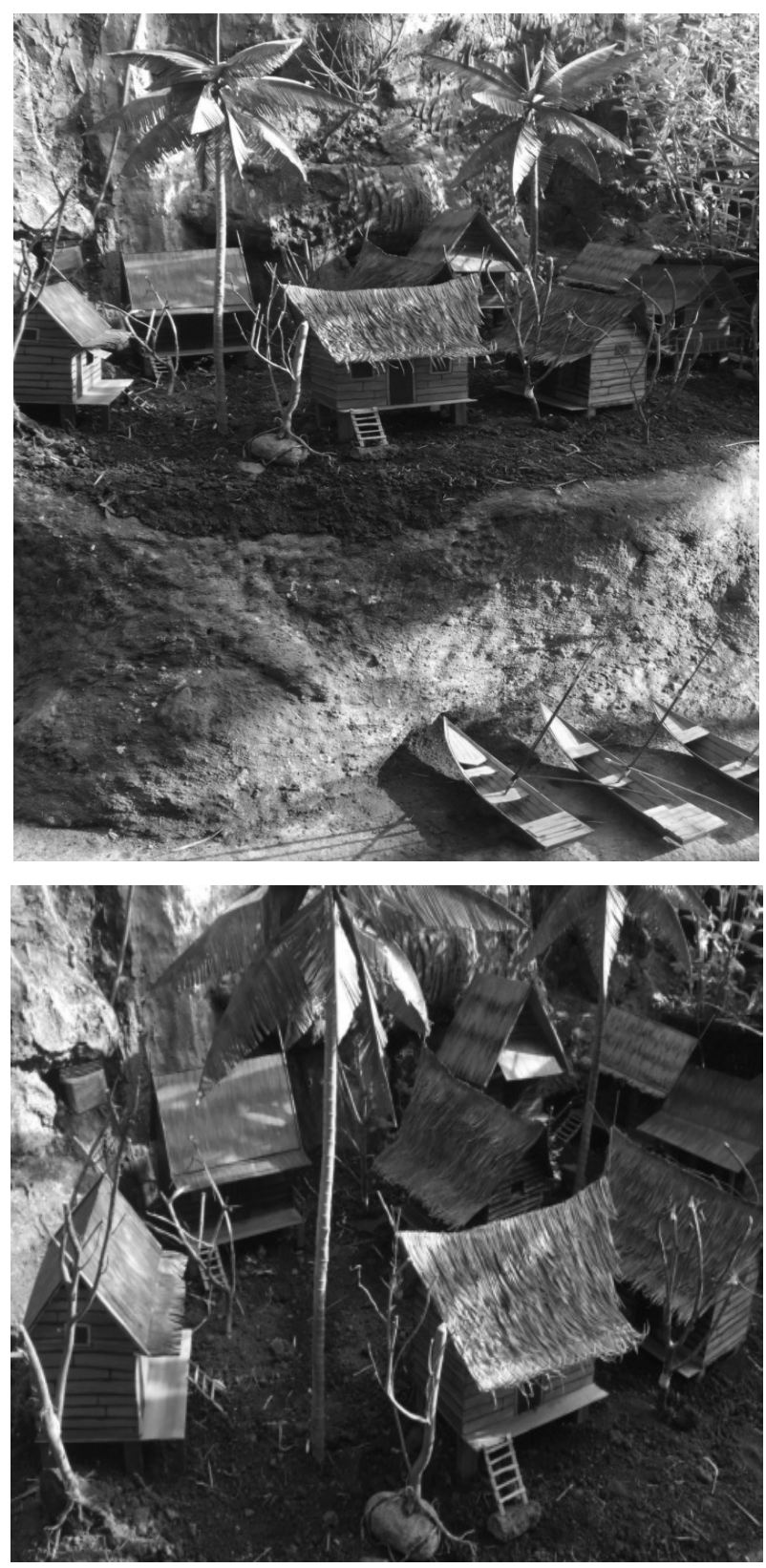

Miniatur kampung Cilela Ambu Hawuk 


\section{Penutup}

Proses penciptaan kreatif yang dilakukan oleh penulis sebagai pencipta naskah drama $\mathrm{Ambu}$ Hawuk menemukan catatan-catatan penting. Bermula dari cerita lisan yang memiliki beberapa varian versi kemudian disatukan menjadi sebuah ide tema, yaitu tentang perjuangan seorang tokoh perempuan melawan kesewenang-wenangan penguasa. Berdasarkan ide tersebut kemudian diwujudkan dalam sebuah naskah drama dengan judul yang sama dengan nama tokoh perempuan dari cerita lisan tadi, yaitu Ambu Hawuk.

Perjuangan seorang perempuan adalah tema dasar dari naskah lakon Ambu Hawuk. Naskah tersebut mencoba membangkitkan kembali semangat feminisme dalam peristiwa-peristiwa yang dijalin dalam legenda Ambu Hawuk. Sistem patriarki masyarakat Sunda lebih sering memandang perempuan sebagai sebuah kaum yang memiliki keterbatasan dibandingkan dengan kaum laki-laki. Pada cerita Ambu Hawuk yang ditransformasikan ke dalam naskah drama Ambu Hawuk digambarkan seorang perempuan yang dianggap berada di belakang laki-laki dan menjadi bayang-bayang seorang laki-laki, muncul menjadi seorang pemimpin. Pemimpin yang berhasil memimpin gerombolan laki-laki untuk melawan penindasan penguasa serta membantu masyarakat, sehingga terbebas dari kesewenangwenangan penguasa.

Melihat kondisi bangsa ini yang hampir tiap saat mengalami keterpurukan moral, pencipta merasa perlu menjadikan kisah ini sebagai refleksi penyadaran manusia akan pentingnya kejujuran dan kemampuan untuk bercermin diri. Manusia harus mampu menempatkan dirinya dengan baik di tengah kekuatan alam semesta. Seharusnya seseorang mampu memikirkan kesengsaraan orang lain dengan cara memberinya banyak bantuan. Pesan yang sebenarnya ingin disampaikan oleh Ambu Hawuk adalah apabila orang-orang kaya dan penguasa mau memperhatikan nasib rakyat miskin, manusia akan mampu hidup saling berdampingan dengan baik.

\section{Kepustakaan}

Danandjaja, James. 2002. Folklore Indonesia, Ilmu gossip, Dongeng, dan lain-lain. Jakarta: Grafiti.

Morthon, Stephen. 2008. Gayatri Spivak, Etika, Subalternitas \& Kritik Penalaran Poskolonial. Yogyakarta: Pararaton.

Pavis, Patrice. 1992. Theatre at the Crossroads of Culture. London: Routledge.

Roehadi, Ayat. 2002. "Citra Perempuan dalam Sastra Sunda" dalam Pikiran Rakyat, 8 Agustus 2002.

Rosidi, Ajip. 2010. Mencari Sosok Manusia Sunda. Jakarta: Dunia Pustaka Jaya.

Soemardjo, Yakob. 2003. Simbol-simbol Artefak Budaya Sunda. Bandung: Kelir. Sunan Ambu Press.

Yudiaryani. 2002. Panggung Teater Dunia Perkembangan dan Perubahan Konvensi. Yogyakarta: Pustaka Gondho Suli. 2009. Melakoni Teater, Serpihan Tulisan tentang Teater. Bandung: Studiklub Teater Bandung. 